\title{
Joint and column behaviour of slotted cold-formed steel studs
}

\section{Andreassen, Michael Joachim; Jönsson, Jeppe}

\section{Published in:}

Proceedings of Nordic Steel Construction Conference 2015

Publication date:

2015

Document Version

Peer reviewed version

Link back to DTU Orbit

Citation (APA):

Andreassen, M. J., \& Jönsson, J. (2015). Joint and column behaviour of slotted cold-formed steel studs. In Proceedings of Nordic Steel Construction Conference 2015

\section{General rights}

Copyright and moral rights for the publications made accessible in the public portal are retained by the authors and/or other copyright owners and it is a condition of accessing publications that users recognise and abide by the legal requirements associated with these rights.

- Users may download and print one copy of any publication from the public portal for the purpose of private study or research.

- You may not further distribute the material or use it for any profit-making activity or commercial gain

- You may freely distribute the URL identifying the publication in the public portal

If you believe that this document breaches copyright please contact us providing details, and we will remove access to the work immediately and investigate your claim. 
Nordic Steel Construction Conference 2015

Tampere, Finland

23-25 September 2015

\title{
JOINT AND COLUMN BEHAVIOUR OF SLOTTED COLD-FORMED STEEL STUDS
}

\author{
Michael J. Andreassen ${ }^{\mathrm{a}}$ and Jeppe Jönsson ${ }^{\mathrm{b}}$ \\ ${ }^{\mathrm{a}, \mathrm{b}}$ Technical University of Denmark, Department of Civil Engineering, \\ Brovej, Building 118, DK-2800 Kgs. Lyngby, Denmark
}

\begin{abstract}
Slotted cold-formed steel studs are used in load bearing external plasterboard walls. The cold-formed steel studs in these walls are supported by and joined to track profiles at the bottom and top level. In this paper the load bearing studs are tested in compression in order to observe the behaviour of the studs and the track joints. The experiments include a joint design with a special web stiffener used in practice. The studs are made of C-profiles and the tracks of U-profiles. Eight different test series are performed. The test series each have different column lengths, thicknesses, and are both with and without web stiffeners to see the influence of these on the joint behaviour and load bearing capacity of the slotted coldformed steel studs.
\end{abstract}

\section{Introduction}

A small number of papers on the strength of load-bearing slotted cold-formed steel members such as $[1,2,3,4]$ have been published. Furthermore only few papers have been published regarding the joints between slotted load-bearing cold-formed steel members such as [5].

In order to observe the behaviour of the studs and joints between slotted cold-formed steel members, this paper presents several tests of studs and joints used for external bearing walls in compression. The slots in the web of the studs considerably change the transverse bending and shear stiffness of the web. This has influence on the local and distortional buckling behaviour of the stud and thus also on the behaviour of the joints.

The experiments are performed in cooperation with a manufacturer and include a joint design made and used by this manufacturer. The studs are C-profiles and the tracks are U-profiles, such that the studs fit into the U-profile, i.e. track profile. Eight different test series are performed, having different column lengths, thicknesses, and are both assembled with and without web stiffeners to see the influence of these on the behaviour and load capacity. Relative short column lengths are used in order to be able to investigate the behaviour of the joints and not only column buckling. The studs are connected to the tracks using four self-tapping screws per joint, two in each side of the flange. 


\section{Test program}

The investigations are performed in order to test and observe the behaviour of the studs and joints as well as to determine the influence of the special joint web stiffener on the load bearing capacity of the external load bearing walls (without influence of the plasterboards). A total of 40 compression tests have been performed in eight different test series each including five tests.

\subsection{Test specimens}

The cross sectional geometry of the tested specimens is shown in Fig. 1 and the slot configuration and dimensions are illustrated in Fig. 2. The thickness of the C-profiles and U-profiles are always identical and is shown in Table 1.
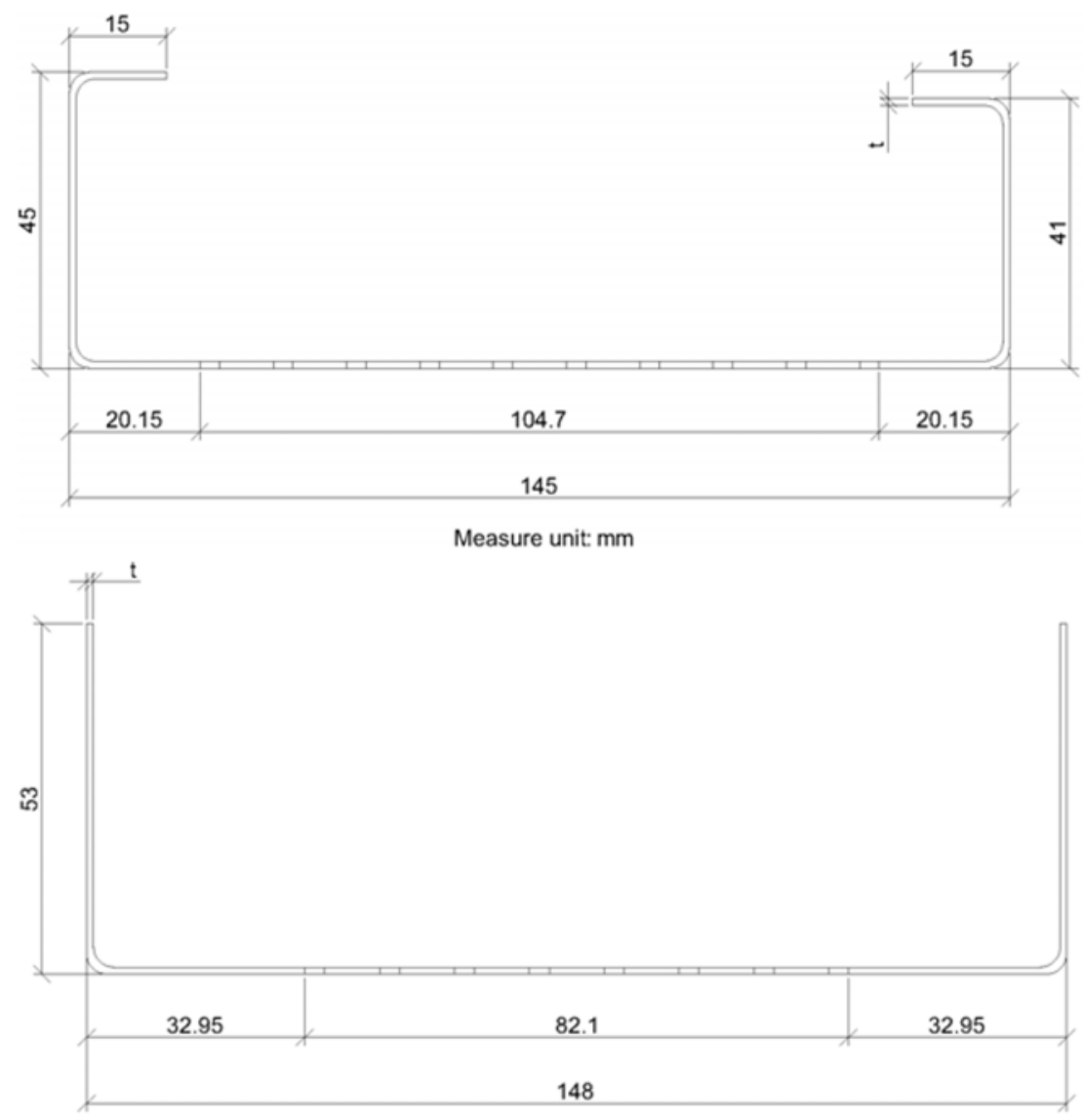

Fig. 1: Cross sectional geometry of C-profiles and U-profiles.

The joint design specified and used by the manufacturer is shown in Fig. 3 both without and with web stiffener. The manufacturer only provides the joint design that includes the web stiffener as shown in Fig. 3 (right).

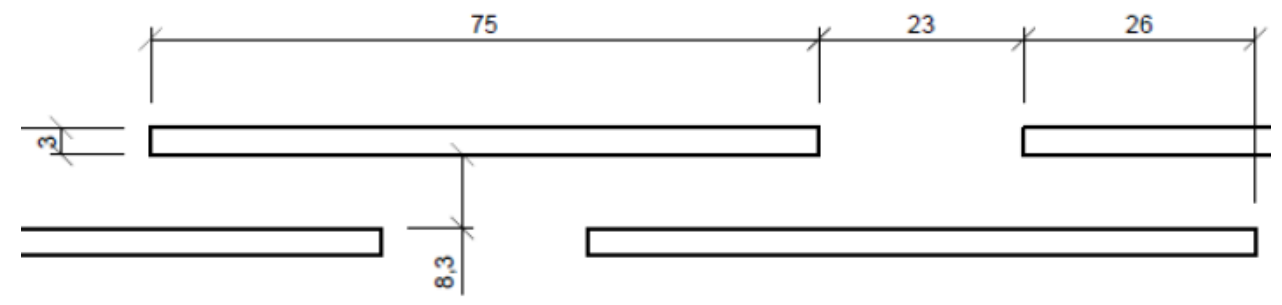

Fig. 2: Slot configuration and dimensions. 

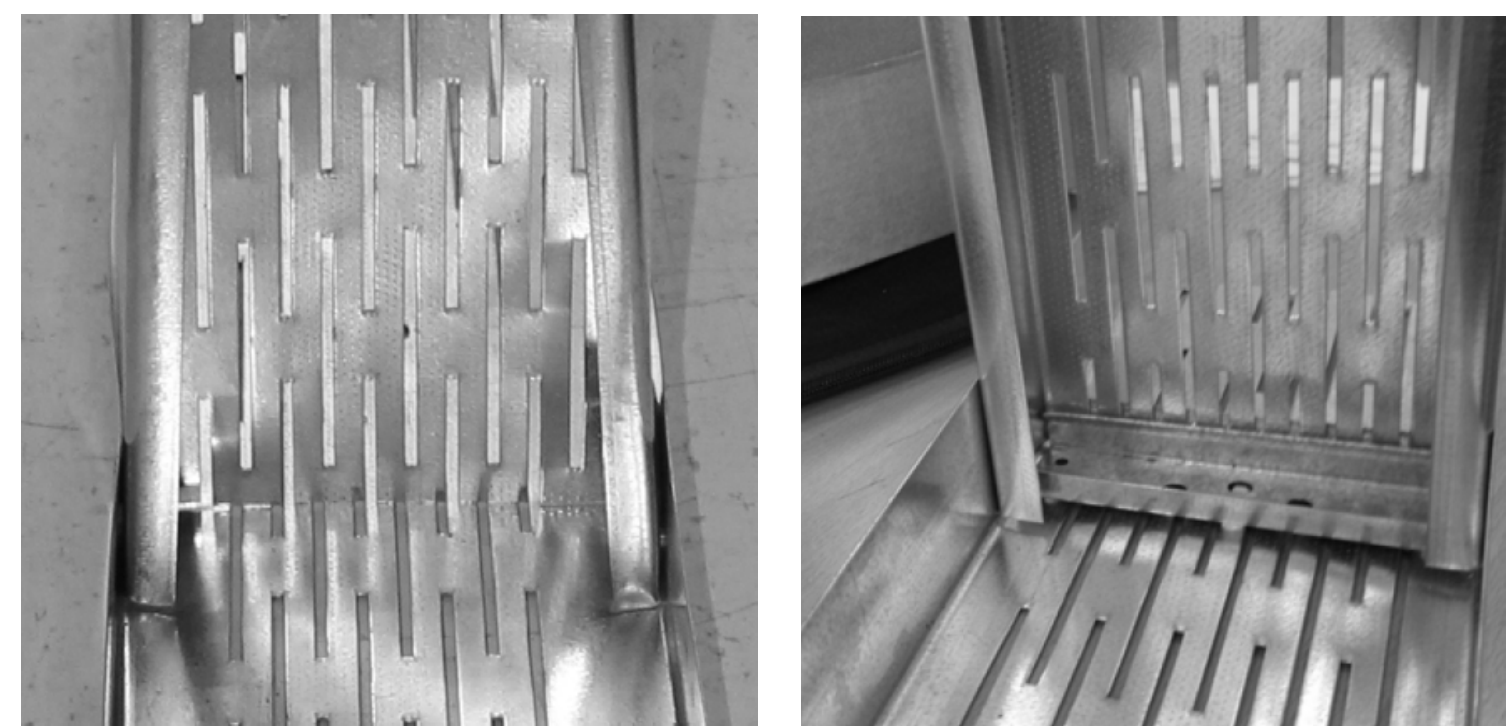

Fig. 3: Connection design without web stiffener and with web stiffener, respectively.

The tests specimens are made with two different column lengths of $1000 \mathrm{~mm}$ and $500 \mathrm{~mm}$, respectively, with two different material thicknesses of $0.7 \mathrm{~mm}$ and $1.0 \mathrm{~mm}$, respectively, as well as with and without web stiffeners. See Table 1 for the actual test element specifications.

Table 1: Test series and specifications.

\begin{tabular}{ccccc}
\hline Test series & Test & $L(\mathrm{~mm})$ & $t(\mathrm{~mm})$ & Web stiffeners \\
\hline 1 & $1-5$ & 1000 & 0.7 & No \\
2 & $6-10$ & 1000 & 0.7 & Yes \\
3 & $11-15$ & 1000 & 1.0 & No \\
4 & $16-20$ & 1000 & 1.0 & Yes \\
5 & $21-25$ & 500 & 0.7 & No \\
6 & $26-30$ & 500 & 0.7 & Yes \\
7 & $31-35$ & 500 & 1.0 & No \\
8 & $36-40$ & 500 & 1.0 & Yes \\
\hline
\end{tabular}

The C-profiles are connected to the U-profiles with self-tapping screws, using QPBT 16 screws as shown in Fig. 4, so that the screws are placed diagonally.

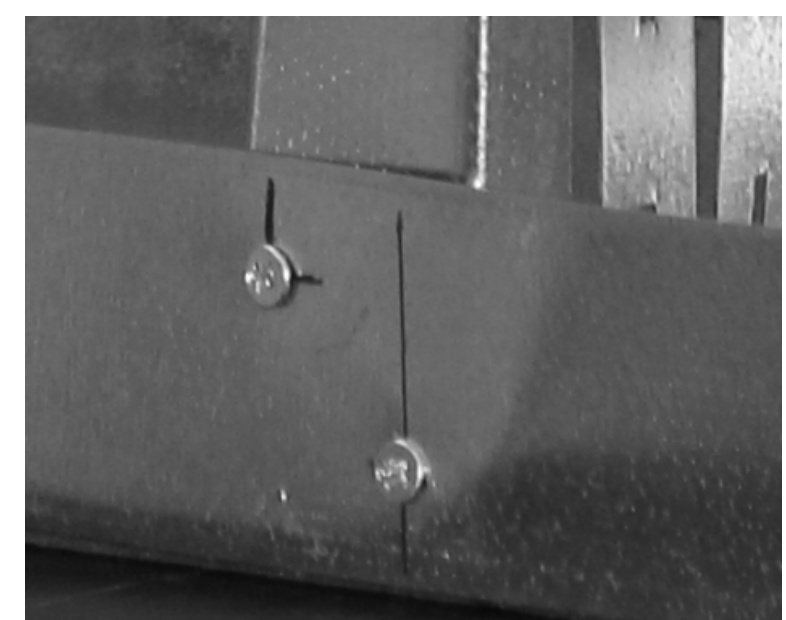

Fig. 4: Connection of C-profile and U-profile with self-tapping screws. 


\subsection{Test setup}

The test setup is as shown in Fig. 5. The U-profiles, i.e. track profiles, are connected to a fixed support block at the top and at the bottom of the specimen, by two bolts in each Uprofile. The bolts are placed for safety reasons, so that the structure does not pop out of the experimental setup. The support blocks are clamped in the testing machine.
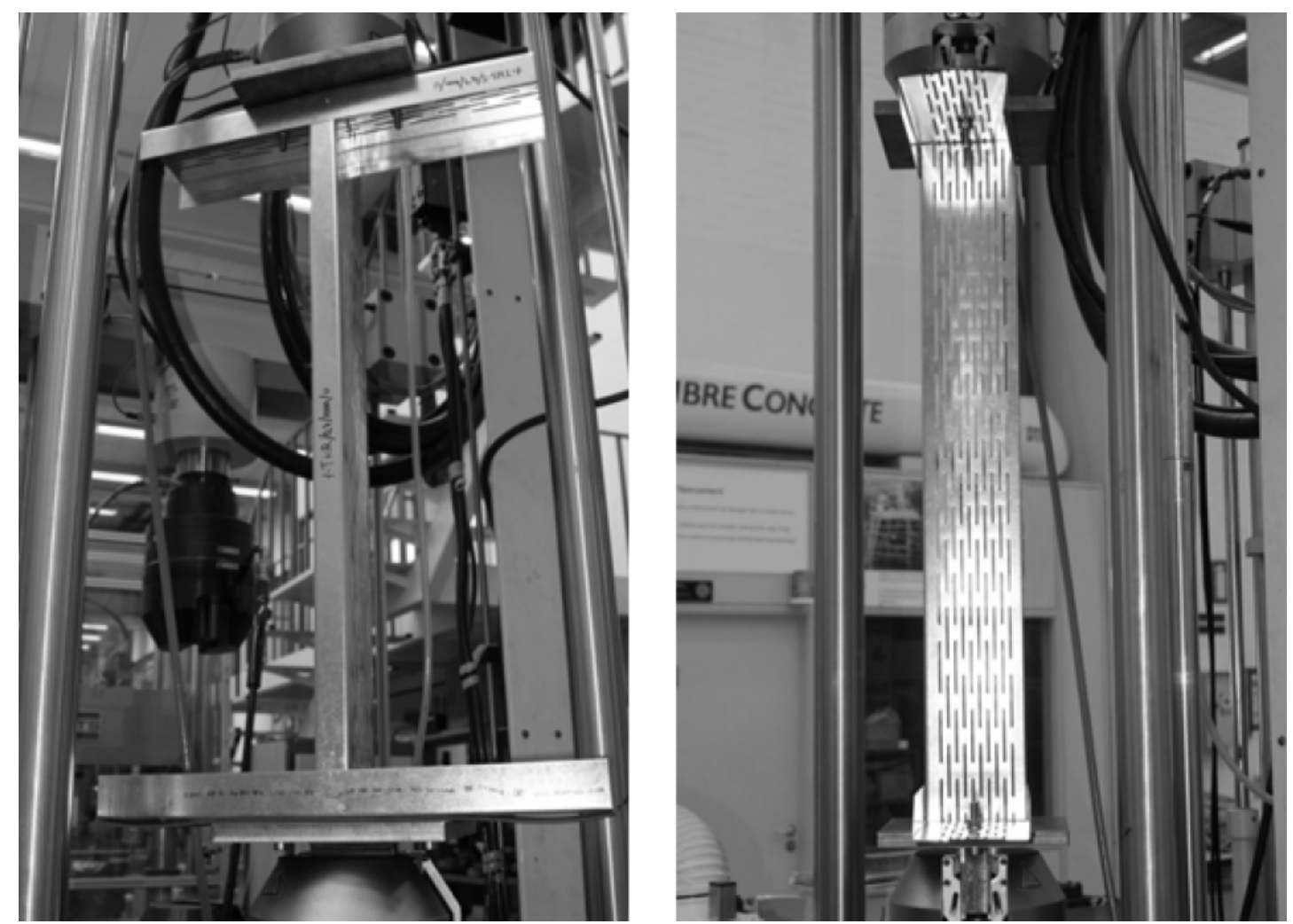

Fig. 5: Test setup.

The fixed support blocks consist of a $260 \mathrm{~mm}$ x $260 \mathrm{~mm}$ x $20 \mathrm{~mm}$ steel plate welded to a 100 $\mathrm{mm} \times 100 \mathrm{~mm} \times 30 \mathrm{~mm}$ plate. The plate block material is S355 structural steel. The fixed support condition is chosen as being part of an external wall connected to the lower and upper floor level.

\section{Material tests and results}

The material data provided by the supplier is structural steel of quality S350GD+Z. The plates used for the cold rolled profiles are hot dip galvanized. According to DS/EN ISO 1461:2009 [6] the zinc coating has a minimum thickness of $20 \mu \mathrm{m}$ on each surface of the specimen. The material properties in the context of the E-modulus and the yield stress and ultimate strength of the steel used for the thin-walled elements are determined by a tensile test. An Instron 8502, $250 \mathrm{kN}$, tension/compression machine is used. Displacement and load is logged by the testing machine with a frequency of $10 \mathrm{~Hz}$ and a stress-strain curve is calculated. An extensometer with a range of $50 \mathrm{~mm}$ is used on the specimen to measure the displacement over an initial distance, which is used to determine the modulus of elasticity. The specimens used for the material tests are randomly chosen from the C-profiles and are cut out after the testing. A total number of 10 specimens have been tested; five specimens with a thickness of $0.7 \mathrm{~mm}$ and five specimens with a thickness of $1.0 \mathrm{~mm}$. The material test setup is shown in Fig. 6 and 
the results in Table 2. Test series 1 is for $0.7 \mathrm{~mm}$ material test specimens and test series 2 is for $1.0 \mathrm{~mm}$ material test specimens.

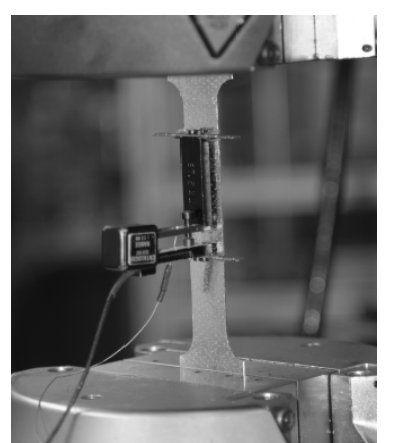

Fig. 6: Material test setup.

Table 2: Material test results.

\begin{tabular}{ccccccc}
\hline $\begin{array}{c}\text { Test } \\
\text { series }\end{array}$ & $\begin{array}{c}\mathrm{f}_{\mathrm{y}, \text { avg. }} \\
(\mathrm{MPa})\end{array}$ & $\begin{array}{c}\text { Standard } \\
\text { deviation }\end{array}$ & $\begin{array}{c}\mathrm{f}_{\mathrm{u}, \text { avg. }} \\
(\mathrm{MPa})\end{array}$ & $\begin{array}{c}\text { Standard } \\
\text { deviation }\end{array}$ & $\begin{array}{c}\mathrm{E} \\
(\mathrm{MPa}) \\
10^{5}\end{array}$ & $\begin{array}{c}\text { Standard } \\
\text { deviation }\end{array}$ \\
\hline 1 & 365.1 & 2.2 & 460.4 & 26.2 & 1.92 & 0.095 \\
2 & 360.8 & 3.1 & 446.4 & 3.0 & 1.81 & 0.049 \\
\hline
\end{tabular}

\section{Results of stud and joint tests}

The results concerning the tests of the studs and joints are divided into two subsections. The first subsection concerns the load bearing capacity of the stud assembly and the second subsection concerns the behaviour of the assembly.

\subsection{Load bearing capacity of the stud assemblies}

The results including the load bearing capacity from the compression tests are shown in Table 3. The results are given in relation to the test series specified in Table 1.

Table 3: Average maximum load capacity for all the tests.

\begin{tabular}{ccc}
\hline Test series & $\mathrm{F}_{\text {max avg }}(\mathrm{kN})$ & Standard deviation \\
\hline 1 & 11.7 & 1.4 \\
2 & 12.9 & 0.6 \\
\hline 3 & 23.5 & 0.9 \\
4 & 23.4 & 0.5 \\
\hline 5 & 14.1 & 0.6 \\
6 & 14.4 & 0.7 \\
\hline 7 & 29.9 & 1.9 \\
8 & 31.4 & 2.0 \\
\hline
\end{tabular}

The test specimens in test series 1 and 2 have a length of $1000 \mathrm{~mm}$, a thickness of $0.7 \mathrm{~mm}$, and are without and with web stiffeners, respectively. From the results is seen that the maximum load is increased by $1.2 \mathrm{kN}$ corresponding to $10.3 \%$ by using the web stiffener. Also less deviation of the results is seen when using the special web stiffener.

The test specimens in test series 3 and 4 have a length of $1000 \mathrm{~mm}$, a thickness of $1.0 \mathrm{~mm}$, and are also without and with web stiffeners, respectively. From the results is seen that the 
maximum load is almost the same for both test series as the difference is only $0.1 \mathrm{kN}$ corresponding to $0.4 \%$ by using the web stiffener. However, less deviation of the results is still apparent when using the web stiffener.

The test specimens in test series 5 and 6 have a length of $500 \mathrm{~mm}$, a thickness of $0.7 \mathrm{~mm}$, and are without and with web stiffeners, respectively. From the results is seen that the maximum load is almost the same for both test series as the difference is only $0.3 \mathrm{kN}$ corresponding to $2.1 \%$ by using the web stiffener. The deviation of the results is also very close for both series.

The test specimens in test series 7 and 8 have a length of $500 \mathrm{~mm}$, a thickness of $1.0 \mathrm{~mm}$, and are also without and with web stiffeners, respectively. From the results is seen that the maximum load is almost the same for both test series as the difference is only $1.5 \mathrm{kN}$ corresponding to $5.0 \%$ by using the web stiffener. The deviation of the results is also very close for both series.

From the results regarding the maximum load capacity it is hereby seen that there is almost no effect by using the web stiffener.

\subsection{Behaviour of the stud assemblies}

An overview of the behaviour and failure type observed in the individual tests (given by the number of the test) is given in Table 4. Generally $1000 \mathrm{~mm}$ long specimens deform in a symmetric distortional mode tending towards closing or opening of the lipped flanges and fail in an interactional global-distortional buckling mode. The $500 \mathrm{~mm}$ short columns sometimes fail in a (symmetric or antisymmetric) local lip or distortional like buckling mode at the joints. It can be seen that the special web stiffeners do have an influence on the behaviour with respect to resisting the closing distortional mode to a certain extent. In the following the behaviour of the structure is further discussed and illustrated in three subsections in relation to both the test series and the behaviour of the structure.

Table 4: Observed failure types for the given test numbers.

\begin{tabular}{ccccccc}
\hline & & & Special & \multicolumn{2}{c}{ Failure type of individual tests: } \\
\cline { 5 - 7 } $\begin{array}{c}\text { Test } \\
\text { se- } \\
\text { ries }\end{array}$ & $\begin{array}{c}L \\
(\mathrm{~mm})\end{array}$ & $\begin{array}{c}t \\
(\mathrm{~mm})\end{array}$ & $\begin{array}{c}\text { web } \\
\text { stiffeners }\end{array}$ & $\begin{array}{c}\text { Distortional } \\
\text { closing }\end{array}$ & $\begin{array}{c}\text { Distortional } \\
\text { opening }\end{array}$ & $\begin{array}{c}\text { Joint } \\
\text { local }\end{array}$ \\
\hline 1 & 1000 & 0.7 & No & $1,3,4,5$ & 2 & \\
2 & 1000 & 0.7 & Yes & 6 & $7,8,9,10$ & \\
\hline 3 & 1000 & 1.0 & No & $11-15$ & & \\
4 & 1000 & 1.0 & Yes & $16-20$ & & $22-25$ \\
\hline 5 & 500 & 0.7 & No & 21 & & \\
6 & 500 & 0.7 & Yes & & & \\
\hline 7 & 500 & 1.0 & No & $31-35$ & & \\
8 & 500 & 1.0 & Yes & $36,37,39,40$ & & \\
\hline
\end{tabular}

\subsubsection{Column lengths of $\mathbf{1 0 0 0} \mathbf{~ m m}$ and thicknesses of $\mathbf{0 . 7} \mathbf{~ m m}$ and $\mathbf{1 . 0} \mathbf{~ m m}$}

In test series 1 to 4 the column length is $1000 \mathrm{~mm}$ as seen from Table 1 and 4 . Even though the columns have different material thicknesses and are fitted with and without web stiffeners, the distortional behaviour and the final failure modes are almost identical. The failure configuration is seen in Fig. 7. 
From test series 1-4 and from Fig. 7 it is seen that even though the column lengths are relatively short, there are no local end failures associated with the joints. The failure mode for all the tests is distortional buckling of the flanges in interaction with global Euler buckling. The profiles buckle in a distortional mode with either closing or opening of the lipped profile.
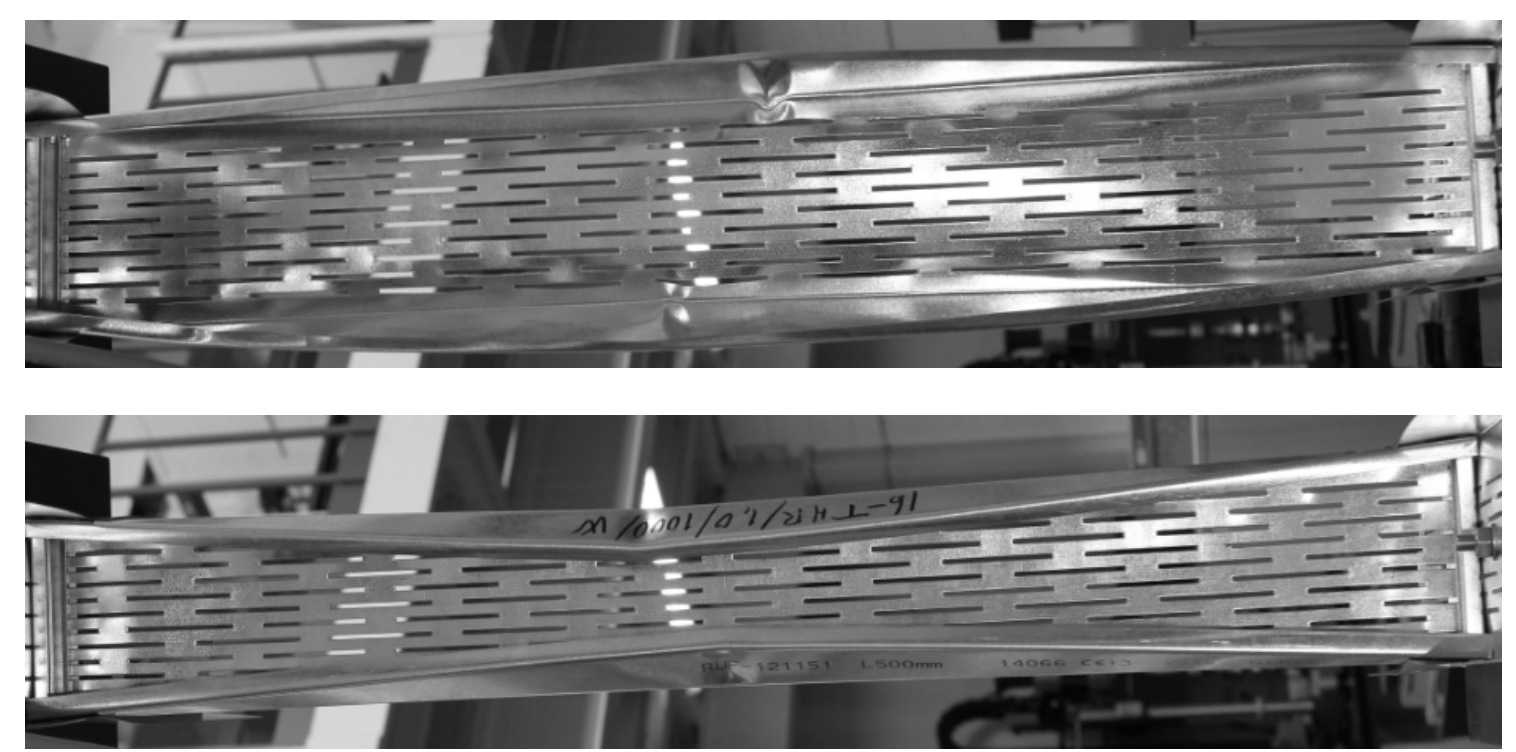

Fig. 7: Failure modes from test series 1-4. Test 8 - distortional opening (upper) and test 16 distortional closing (lower).

From Fig. 8 and Fig. 9 the respective joints of column test 8 and 16 are shown. From these figures it is clear that there is no joint failure only some local deformation of the flanges of the track profile.

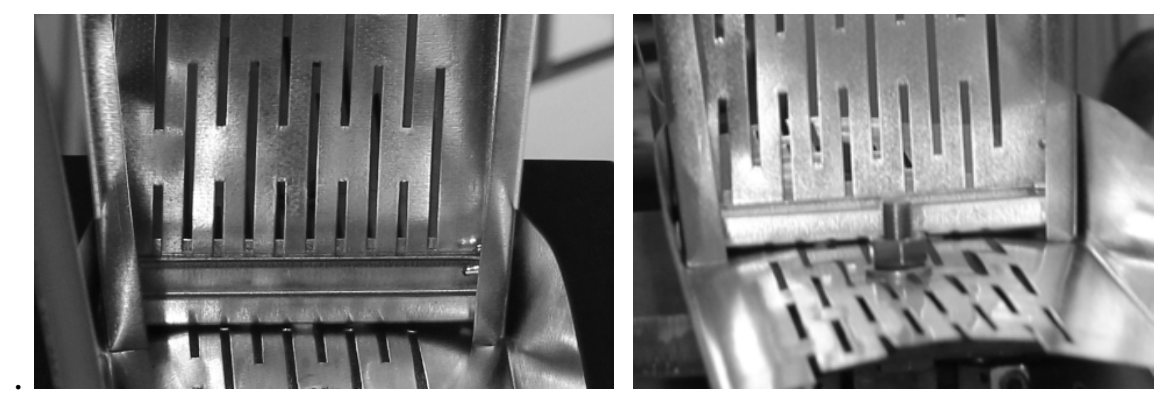

Fig. 8: Test 8 top and bottom, respectively.

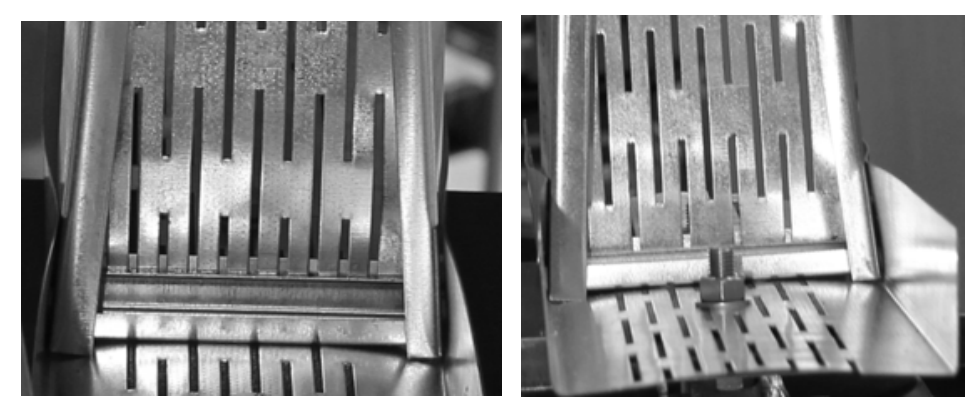

Fig. 9: Test 16 bottom and top, respectively.

In Fig. 10 the deformed web end is seen for test 12 and 9. As seen from the figure, test 12 is without a web stiffener and test 9 is with a web stiffener. Here it is clear that the web just acts 
like a vertical spring and that almost all the load is transferred through the flanges and the lips and there is no local failure.
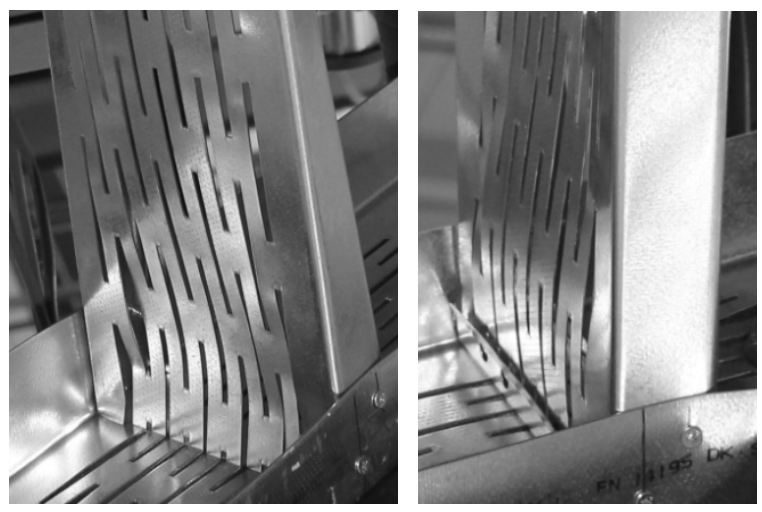

Fig. 10: End deformation of test 12 and 9, respectively.

As also seen from the ultimate loads in Table 3, there seems to be no direct effect of the web stiffeners. However the standard deviation does decrease and for the thinnest profile in test series 2 does give a seemingly small increase in load bearing capacity.

\subsubsection{Column lengths of $\mathbf{5 0 0} \mathbf{~ m m}$ and thicknesses of $\mathbf{0 . 7} \mathbf{~ m m}$}

In test series 5 and 6 the column length is $500 \mathrm{~mm}$ and the profile thickness is $0.7 \mathrm{~mm}$ as seen from Table 1. Unlike the previous test series with a column length of $1000 \mathrm{~mm}$, different failure modes are now seen from the experiments, see Table 4. In Fig. 11 it can be seen that both closing and opening distortional modes develop and the profiles fail in an interactional mode of global column buckling in interaction with the developing distortional buckling mode.
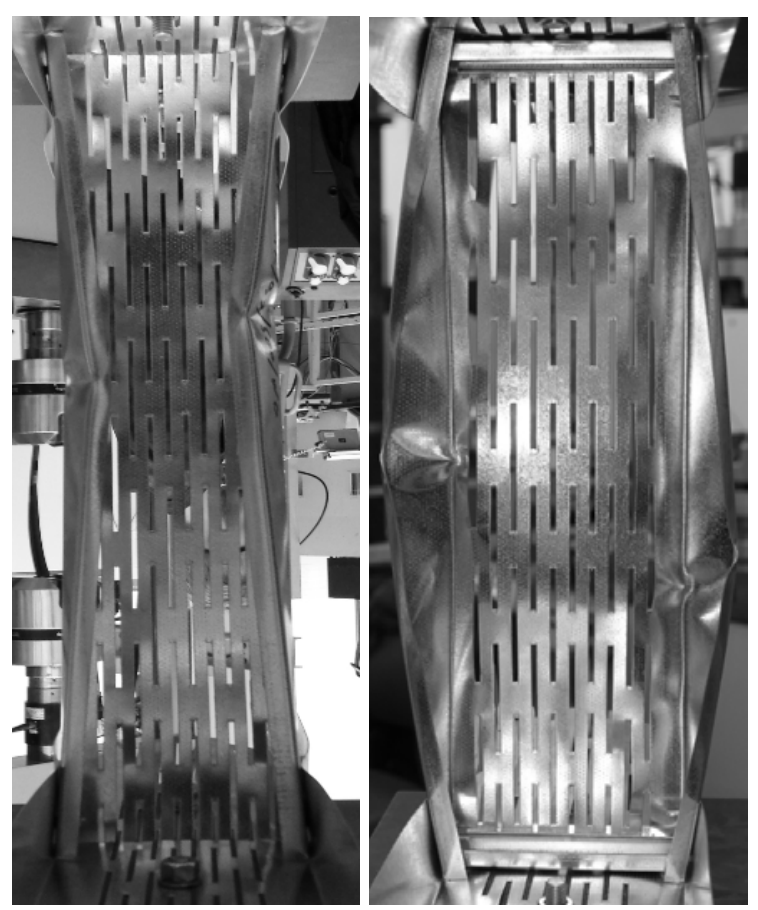

Fig. 11: Test 21, 26, respectively.

However as seen in Table 4, a lot of local end joint failures also happen now. These can be seen in Fig. 12 and Fig 13. Fig. 12 shows the end failures of the columns without web stiffeners, and Fig. 13 shows the end failures of the columns with web stiffener. Most of the tests 
including an end failure also include an interactional distortional-column stability failure close to the middle of the column.
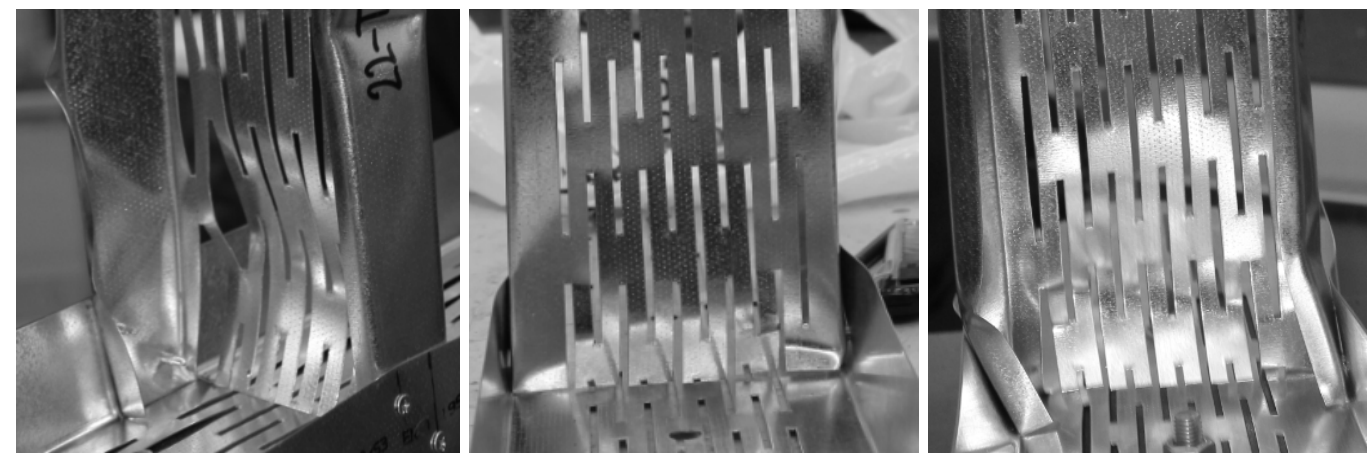

Fig. 12: Test 22, 23, 24, respectively. Without web stiffener.
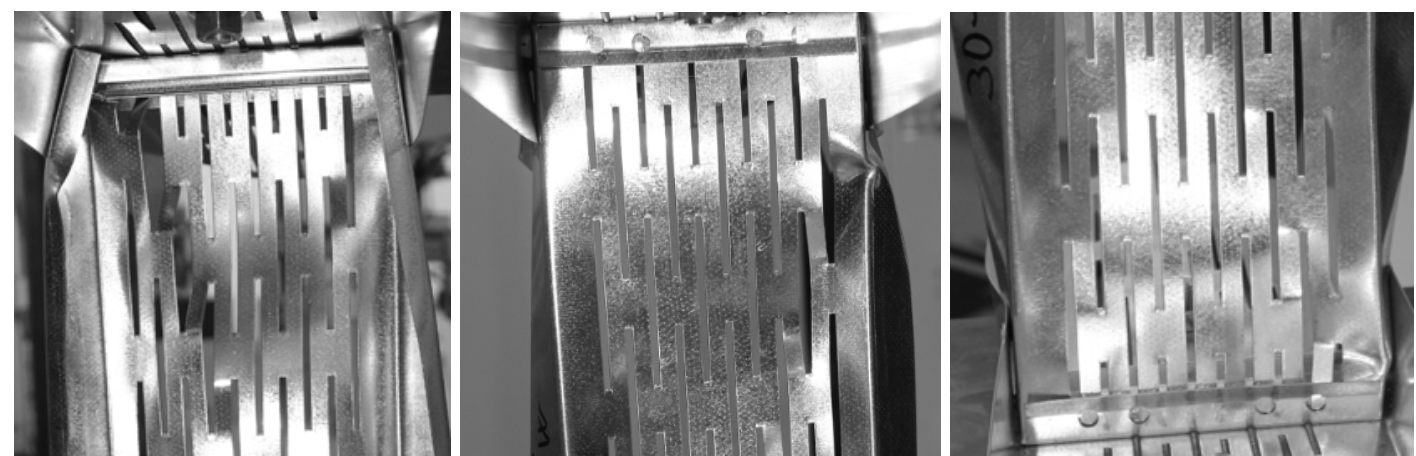

Fig. 13: Test 27, 28, 30, respectively. With web stiffener.

\subsubsection{Column lengths of $\mathbf{5 0 0} \mathbf{~ m m}$ and thicknesses of $\mathbf{1} .0 \mathrm{~mm}$}

In test series 7 and 8 the column length is $500 \mathrm{~mm}$ and the profile thickness is $1.0 \mathrm{~mm}$ as seen from Table 1. From test 31-35 which is without a web stiffener the failure mode for all the tests is interactional global-distortional buckling as shown in Fig. 14.

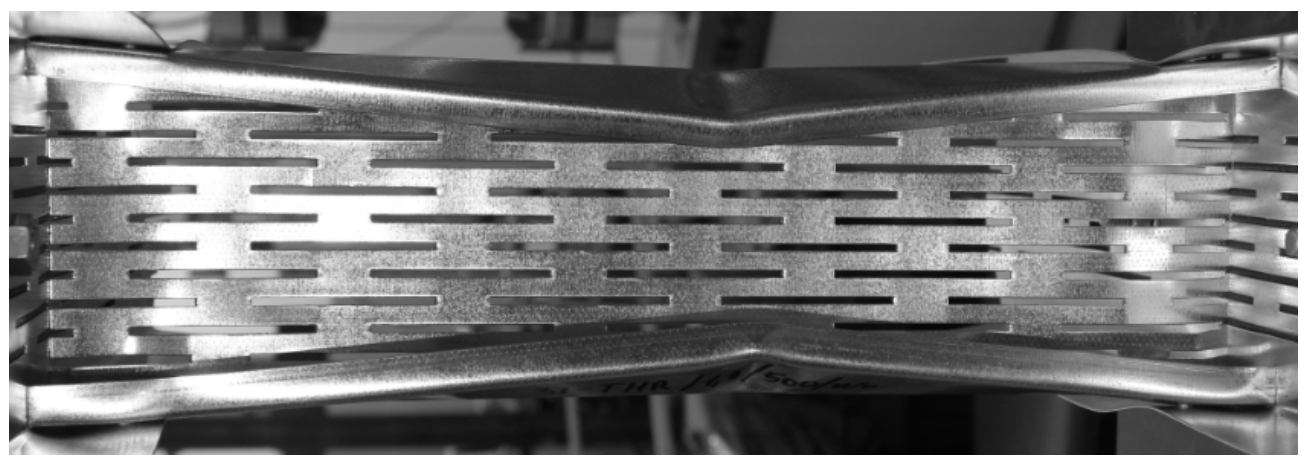

Fig. 14: Test 31. Without web stiffener.

From test 36-40 which are fitted with a web stiffener, end failures can now be seen in combination with an interactional global-distortional failure mode as shown in Fig. 15. 


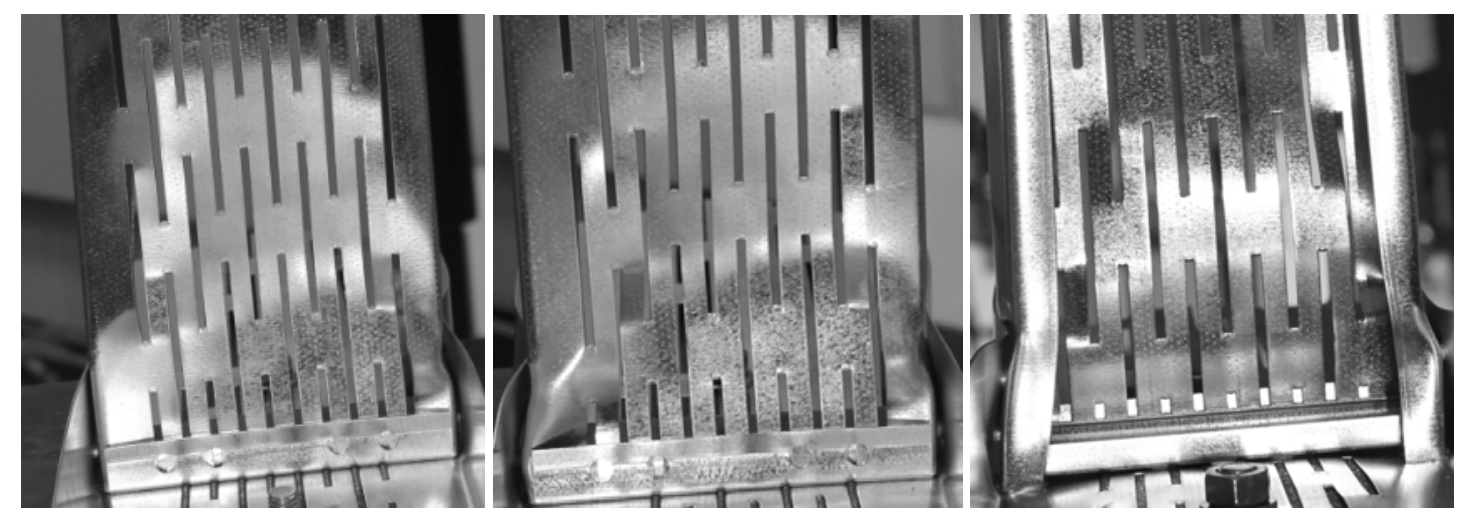

Fig. 15: Test 36, 37 and 38, respectively. With web stiffener.

The failure mode for test 36 is a combination of an end failure and an interactional globaldistortional stability failure close to the middle of the column in a single flange, while test 38 only has local end failures.

\section{Conclusions}

The conclusion regarding the maximum load capacity is that there is no effect of using the special web stiffener. Regarding the failure modes the conclusion is that almost the same failure modes occurs with and without joint stiffeners. Even for relatively short and thin columns, with a length of $1000 \mathrm{~mm}$ and a thickness of $1.0 \mathrm{~mm}$ and $0.7 \mathrm{~mm}$, respectively, the failure configuration is an interactional global-distortional stability failure of the flanges close to the middle of the column. This is also the case for columns with a length of $500 \mathrm{~mm}$, a thickness of $1.0 \mathrm{~mm}$ and without web stiffeners.

Having a column length of $500 \mathrm{~mm}$ with a thickness of $1.0 \mathrm{~mm}$ and with web stiffeners as well as a column length of $500 \mathrm{~mm}$ with a thickness of $0.7 \mathrm{~mm}$ without and with web stiffeners, the failure configurations is a combination of an end failure and an interactional globaldistortional stability failure close to the middle of the column.

\section{References}

[1] Thöyrä T. "Strength of slotted steel studs”, PhD thesis, Royal Institute of Technology, Department of Structural Engineering, Stockholm, Sweden, 2001.

[2] Höglund T. "Beräkning av slitsad tunnplåtsregel”, Report 42, Royal Institute of Technology, Department of Structural Engineering, Stockholm, Sweden, 1999.

[3] Borglund J., Jonsson J. “Bärförmåga för slitsade stålreglar”, M.Sc. thesis 84, Royal Institute of Technology, Department of Structural Engineering, Stockholm, Sweden, 1997.

[4] Kesti J., Mäkeläinen P. “Compression behavior of perforated steel wall studs”, LightWeight Steel and Aluminium Structures, 123-130, Finland, 1999.

[5] Costa M.M. "Support Strength of walls with slotted studs”, M.Sc. thesis 127, Royal Institute of Technology, Department of Structural Engineering, Stockholm, Sweden, 1999.

[6] DS/EN ISO 1461:2009, Hot dip galvanized coatings on fabricated iron and steel articles - Specifications and test methods, European Standard. 